Reprod. Nutr. Dévelop., 1980, 20 (5 A). 1515-1526.

\title{
Membrane differentiation in the pregastrula of the teleost, Brachydanio rerio Hamilton-Buchanan (Teleostei : Cyprinidae). A scanning electron microscope study
}

\author{
par P. ROUBAUD, Catherine PAIRAULT \\ Technical assistance : - Aquariology, A. NEUVIC, J. Y. SIRE ; - TEM, F. ALLIZARD ; - SEM, \\ F. MEURY
}

Laboratoire de Physiologie des Poissons, INRA, 78350 jouy-en-josas.

Laboratoire d'Anatomie comparée, Equipe de Biologie du Développement, Paris VII, 2, place Jussieu, 75221 Cedex 05, Paris, France.

Summary. The pregastrula stages of the teleost, Brachydanio rerio, have been studied in intact or fractured eggs by scanning electron microscopy.

The internal surface of the enveloping blastomeres was smooth, while the external surface was covered with cristae ; these cristae disappeared during epiboly but reappeared when the cells were in mitosis. At the end of the morula stage, the smooth yolk cytoplasmic layer formed a ring of periblastic cristae ; up to the late blastula stage that ring was attached to «star-like » complexes. Light and transmission electron microscopy images of these complexes are given and we propose hypotheses regarding their function.

At first closely apposed, the deep cells seemed to be maximally dispersed during the mid-blastula stage.

At the blastula stage, the yolk syncitium formed both envelopping and deep cells. This suggests a primordial role of the yolk syncitium layer in pregastrula differentiation.

A new hypothesis concerning the functions of the membrane protrusions is proposed : they might play a role in the postmitotic reassociation of the blastomeres. We suggest that, during early development, the three modes of cell association, i. e. monolayer, mass aggregation, syncitium, might be correlated with the composition of the three media (perivitelline liquid, blastocoelic liquid, yolk) present at that time.

\section{Introduction.}

Scanning electron microscopy (SEM) techniques have only been recently applied to the study of membrane surface changes during early egg development in teleosts. After Hart et al. (1977) reported on the cortical reaction of the Brachydanio rerio egg, Boulekbache and Devillers (1977) furnished the first elements of an overall description of the membrane structures in Salmo irideus from the activation period to the end of gastrulation (fig. A). The enveloping surface showed a network of cristae which, at gastrulation, transformed into a meshwork of microvilli ; the periphery of the yolk syncitium (periblast) remained smooth and the deep cells presented lamellipodial and 
filopodial processes. Mitosis was manifested by the disappearance of the membrane protrusions, except in the zone of the division furrow.

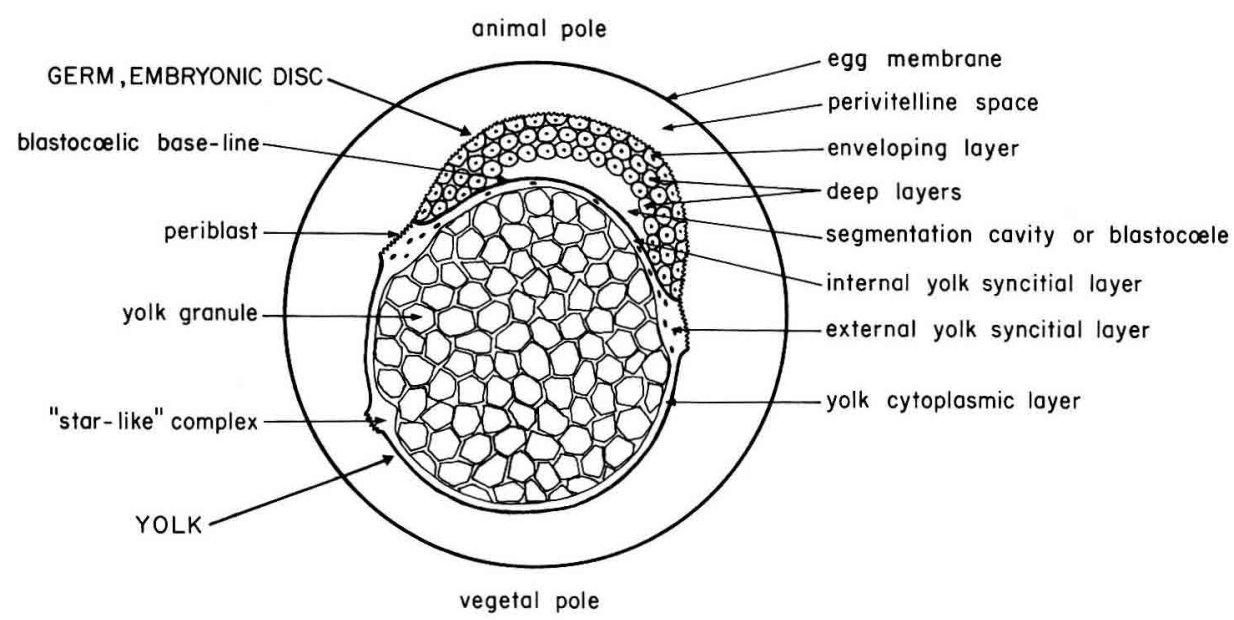

FIG. A. - Diagram representing the late blastula stage of Brachydanio rerio.

These same authors accompanied their description by a review of the possible functions of the various membrane protrusions, and proposed the following : membrane storage for cytodieresis and epibolic spread; increased cell surface exchanges, especially respiration ; deep cell locomotion ; substrata for surface antigens.

In 1978, Thomas and Waterman studying Brachydanio rerio and Betchaku and Trinkaus Fundulus heteroclitus reported images of membrane changes between the blastula stage and the end of epiboly. The former authors gave special attention to the aspect of the deep cells; they indicated that new enveloping cells are continuously formed from the yolk syncitium, and suggested that this process could explain epibolic spread.

On the contrary, Betchaku and Trinkaus excluded the intervention of such cell formation during epiboly ; epiboly would result from a passive spreading of the enveloping layer, initiated by the contraction of the syncitial ring of the periblast. This contraction, which gradually spreads to the zone of the vegetal pole, would be expressed in the membrane by a folding of the external syncitial surface and the simultaneous unfolding of the marginal surface of the blastocoelic base-line and of the external surface of the enveloping layer.

While present research on the development of membrane structures seems to be oriented to problems of gastrulation and epiboly, in the present paper, we have tried to complete the SEM study of the teleost egg, particularly during the pregastrula stages. In fact, large modifications occur in the trout egg at mid-blastula stage. Respiratory activity increases (Boulekbache ef al., 1969), germ " dissociativity » (Coupe et al., 1974 ) is at a maximum and a new isozymatic type of lacticodehydrogenase appears 
(Boulekbache, Rosenberg and Joly, 1970). However, various observations indicate that this enzyme plays a leading role in differentiation and early organogenesis (Roubaud et al., 1976 ; Boulekbache, Roubaud and Devillers, 1976).

\section{Material and methods.}

Fish. - Breeding fish 8 to 18 months old were kept at $26^{\circ} \mathrm{C}$ under a 14-hr daylight ratio. In those conditions, eggs were laid every 5 days in the hour following lights-on in the fish room. As soon as laying was observed, the eggs were systematically sampled every hour for $7 \mathrm{hrs}$ up to the mid-epiboly stage.

Sample preparation and observation. - As determined for the trout egg by Boulekbache and Devillers (1977), we used fixators with $290 \mathrm{mOsm} / \mathrm{l}$. Although the images obtained with SEM were of the same quality between 170 and $320 \mathrm{mOsm}$, trials for TEM (Thomas, 1968) led us to choose 172 mOsm (osmolarities were calculated from Busson-Mabillot, 1971).

The samples were fixed for $1 \mathrm{hr}$ in $1.25 \mathrm{p} .100$ glutaraldehyde, rinsed for $15 \mathrm{~min}$ and then postfixed $1 \mathrm{hr}$ in $1 \mathrm{p} .100$ osmic acid and rinsed again for $12 \mathrm{hrs}$. All the solutions were buffered at $\mathrm{pH} 7.5$ by a sodium cacodylate- $\mathrm{HCl}$ mixture.

The preparation and observations of the samples were carried out according to the techniques defined for the trout egg by Boulekbache and Devillers (1977). The samples were fractured after drying to observe the internal structures.

\section{Results.}

\section{A. - External surfaces.}

Enveloping layer. - From the undivided egg up to the beginning of epiboly, the external layer of the embryonic disc is covered with a continuous network of cristae. The first division furrows appear in the form of smooth patches with short cristae and microballs (" microboules»: Boulekbache and Devillers, 1977) (fig. 1). Up to the 16-cell stage, small circular depressions are visible which may represent the end of cortical vacuole expulsion. From the blastula stage, the cells are separated by limiting ridges (fig. 2) which are visible during and after epiboly and become more evident as the surface of the enveloping layer becomes smooth. At this time, only a few cells at the end of mitosis have cristae (fig. 3).

External yolk syncitial layer. - Up to the morula stage, the whole external yolk surface remains smooth. From the late morula, the aspect of the margin of the embryonic disc indicates that new enveloping blastomeres are forming from the periblastic syncitium. We observed successively:

- the fragmentation of the periblastic zone into patches with cristae (fig. 4) delimited by patches of membrane which are at first smooth, then covered with microballs (fig. 5) ;

- the formation of deep indentations (figs. 5, 6) where the alreaady formed blastomeres are in contact ; 
- the swelling of the previously delimifed neighboring zones (fig. 6) which become covered with cristae and are demarcated by limiting ridges.

At the blastula stage, cells may be formed as a direct effect of the delimitation of a circular depression.

The intensity of cell formation in the syncitial layer seems to be maximum at the mid-blastula stage; at epiboly, the ring of syncitial cristae continues to encircle the germ, but only a small number of sites are seen which appear to be involved in cell formation.

Yolk cytoplasmic layer. - This layer remains constantly smooth (fig. 4) and presents an undulating, mosaic-like aspect due to subjacent yolk granules. At the blastula stage, and particularly when blastomere formation by the syncitium seems most intense, a network of large folds is seen which is organized gradually into " star-like » complexes (figs. 7, 9). These complexes are composed of a central disc covered with short cristae which are more or less abundant (figs. 8,9$)$; some of the folds extending from the disc regain the network of the syncitial folds.

(The long arrow indicales the direction of the animal pole.)

FIGS. 1-6. - Enveloping layer and periblastic zone.

FIG. 1. - Two-cell stage. Lines of microballs along the division furrow. $\times 1800$.

FIG. 2. - Blastula stage. UP to epiboly the enveloping layer is covered with a network of cristae; at the margin of the yolk syncitium (ysl) limiting ridges (arrows) separate the blastomeres. $\times 900$.

FIG. 3. - Mid-epiboly stage. The blastomeres are smooth, except at the end of mitosis; the surface over-lying the nuclei $(n)$ bulges; a limiting ridge (arrow) separates cells. $\times 940$.

FIG. 4. - Early blastula siage. Membrane patches on the yolk syncitial layer (ysl). Patches are covered with a network of cristae ; yolk cytoplasmic layer is smooth. $\times 480$.

FIG. 5. - Morula sfoge. Lines of microballs converge towards the depressions on the margins of forming membrane patches. $\times 700$.

FIG. 6. - Morula stage. A newly-formed cell is isolated by a limiting ridge (arrow). A line of short cristae (arrow) extends over the yolk syncitial layer (ysl). $\times 1800$.

FIGS. 7-13. - Stor-like complexes.

FIG. 7. - Lafe morula stage. Yolk syncitial layer (ysl) during folding is connected to the yolk cytoplasmic layer $(\mathrm{ycl})$ in wich starlike complexes (arrow) are forming. $\times 130$.

FIG. 8. - Early blastula stage. View of a star-like complex : the membrane protrusions on the central disc are crowded together. $\times 1200$.

FIG. 9. - Late morula stage. A star-like complex in formation. $\times 1800$.

FIG. 10. - Blastula stage. A star-like complex seems to be integrating into the yolk syncitial layer (ysl). $\times 1350$.

(to be continued) 


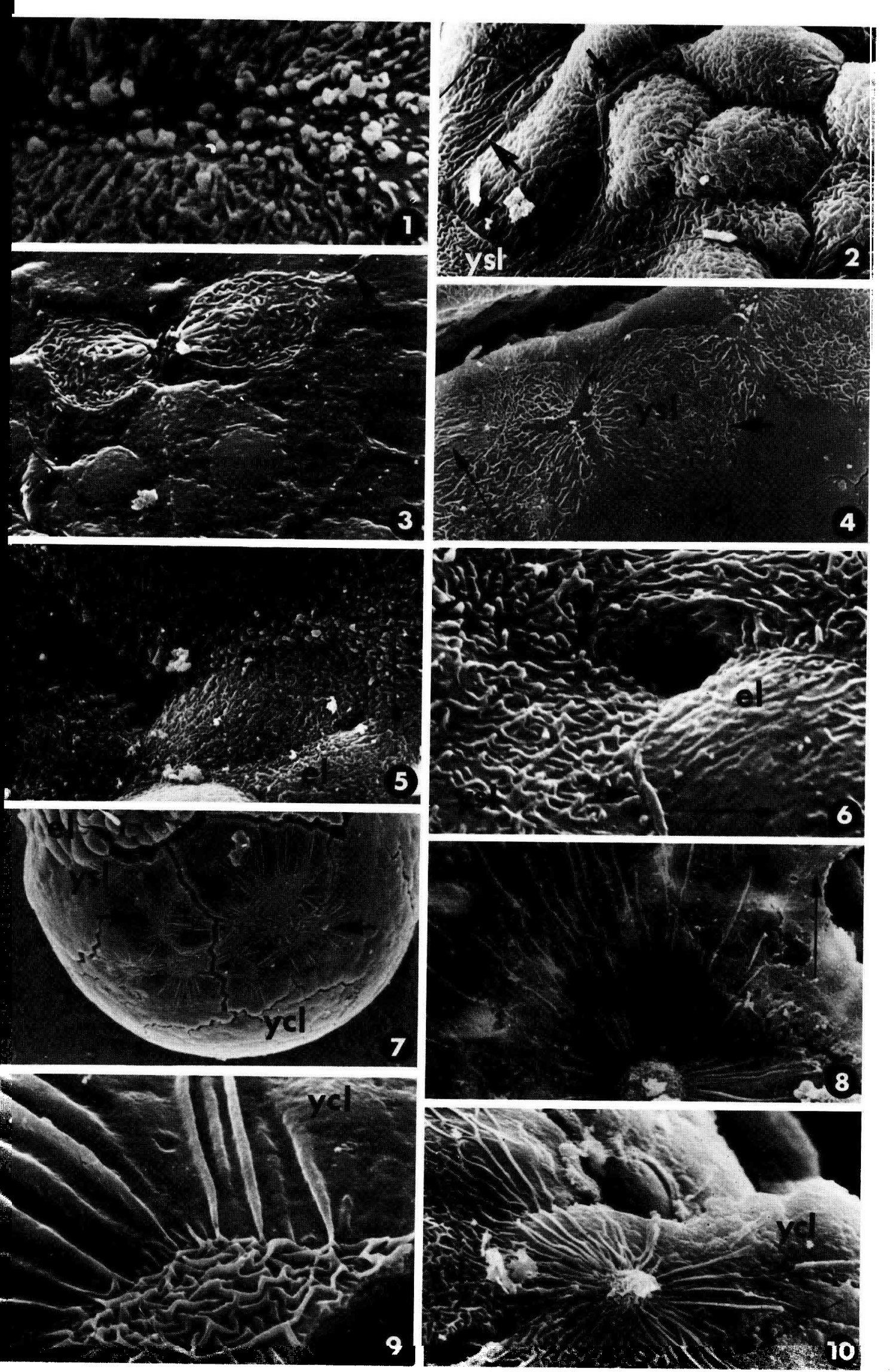


Several «star-like» complexes are localized around the equator, sometimes forming « double stars» (fig. 11). Their existence appears to be limited to the pregastrula stage, but we have not been able to determine if their appearance is necessary for development. Semi-thin sections of the central disc of the complexes observed under a light microscope with an immersion system (fig. 12), show an hemisphere bristling with cristae and resting on a dome-shaped thickening of the yolk cytoplasm containing small yolk granules. This structure also appeared under TEM. However, the image of one sample shows a different aspect (fig. 13). The central disc is only slightly domed and has a round indentation whose rim is protected by a wrinkled fold of the membrane. The electron-dense bottom of the indentation seems to be the confluence point of the small yolk granules, some of which are disaggregating.

\section{B. - Deep layers.}

The cells on the blastocoelic side of the enveloping layer present a smooth surface resembling that of the neighboring deep cells. At the late morula stage (fig. 15), the latter adhere closely so that when separated, they leave some material from the cytoplasm and the membrane. A similar process occurs at the contact of the yolk syncitial layer, permitting localization of the cells adhering there.

At the mid-blastula stage, the deep cells (fig. 16) seem more dispersed than at previous stages. Only a few maintain contact through their lamellipodia and short

FIGS. 7-13. - Star-like complexes (end).

FIG. 11. - Early blastula stage. A « double-star » complex on the yolk cytoplasmic layer. $\times 1000$.

FIG. 12. - Early blastula stage. Semi-thin section of a star-like complex under light microscopy with an immersion system; $\mathrm{yg}=$ yolk granule. $\times 4000$.

FIG. 13. - Lafe morula sfoge. Sample observed under TEM. The central disc of the forming star-like complex has a round indentation with a wrinkled rim. $\times 3400$.

FIGS. 14-19. - Deep surfaces.

FIG. 14. - Blastula stage. External enveloping layer (eel) is wrinkled while the internal enveloping layer (iel) is smooth. $\times 3240$.

. FIG. 15. - Morula stage. Deep cells (dc) are apposed by adhesive discs; the places where the cells have been torn apart are visible. $\times 1080$.

FIG. 16. - Mid-blastula stage. Deep cells (dc) are rounded and slightly adhesive. $\times 650$.

FIG. 17. - Late blastula stage. Deep cells (dc) apposed to the enveloping layer (el) and to the internal yolk syncitial layer (iysl) by short lobopodia and lamellipodia (arrows). $\times 1800$.

FIG. 18. - Blastula stage. Internal yolk syncitial layer (iysl) extends short lobopodia (arrow) towards the deep cells $(\mathrm{dc}) . \times 1800$.

FIG. 19. - Blastula stage. The germ has detached; the external yolk syncitial layer (eysl) is crested and the internal yolk syncitial layer (iysl) is smooth. This layer forms a slope (arrow) where deep cells seem to form. $\times 700$. 
lobopodia ; some cells are connected to the surface of the yolk syncitium (fig. 17), which may extend towards them short adhesive prolongations (fig. 18). At the blastula stage, the domed internal yolk syncitial layer forms a peripheral ring-shaped rim to which deep cells appose ; the presence of rounded protrusions suggests that new deep cells might be formed by the yolk syncitium.

\section{Discussion.}

Cell formation by the yolk syncitium.

Our observations show the role of the yolk syncitium in the formation of two main cell types which differentiate on the embryonic disc.

Kopsch (1900) observed that the yolk syncitium formed new deep cells. In 1978 , Thomas and Waterman reported the appearance of new enveloping cells of syncitial origin from the late blastula stage. According to these authors, this process could play a determining role in spreading the enveloping layer during epiboly. In this paper, we have described the stages of the syncitial formation of enveloping cells. Some aspects may be compared to the images observed when the first division furrows are formed (figs. 1,5 ).

The formation of new enveloping cells of syncitial origin may be seen in SEM from the morula stage. This formation might be the simple prolongation of some cytokinetic characteristics observed during the first segmentation divisions. The first cell layer formed at the 8-cell stage already presents a syncitial aspect, and the first enveloping blastomeres are formed from a syncitial layer. Syncitial cell formation in the Brachydanio rerio egg thus begins much earlier than has been reported previously (Thomas and Waterman, 1978), but slows down considerably from gastrulation. It therefore cannot play a determining role in epiboly.

«Star-like » complexes.

Due to the yolk properties, it is difficult to prepare histological sections of fish eggs for either light or TEM microscopy. The thin yolk cytoplasm layer is particularly difficult to preserve. This might explain why the observation of this zone has been neglected up to now. Previous authors tried to eliminate the yolk mass as much as possible by detaching from it the germ zone which they were studying.

In SEM, critical-point drying of the samples often induces retraction, especially at the margin between the germ and the periblast. Thus, it is tempting to attribute the presence of the "star-like » complexes to artefacts. However, these complexes seem to be normal aspects of Brachydanio rerio egg development for several reasons :

- osmotic shock cannot explain their formation; they appear after fixation in media of low osmolarity (170 mOsm) which give satisfactory results in TEM ;

- TEM images show no particular degradation of their cytological structures ;

- the continuity of the radiating cristae (fig. 10 ) with that of the periblastic syncitium prevents excluding the existence of the former without having to reject that of the latter.

The «star-like » complexes seem to be present only during a well defined phase of development, from the morula to the midblastula stage. 
They do not appear to be of a cellular nature since we have not been able to see a nucleus. Their functional significance is unknown but we suggest three possibilities : (i) the center of the complex may be a traction zone inducing egg surface tension. The complex shows how the clusters of contractile microfilaments in the underlying membrane are organized. These microfilaments invade the yolk cytoplasmic layer and integrate into the yolk syncitium at epiboly ;

(ii) the «star-like » complex may express the ability of the yolk cytoplasm to partition into cellular patches; this ability becomes evident during syncitial cell formation. The center of the complex may be compared (Joly, 1978, personnal communication) to the basal corpuscle described by Gipson (1974) in the division furrow of the chicken blastodisc at the 2, 4 and 8-cell stages. The slight thickening of the yolk cytoplasm would prevent it from sinking into a division furrow. The whole complex would thus be visible on the surface, the radiating cristae corresponding to the folds which, on the chicken blastodisc, run along the sides of the division furrow ;

(iii) the «star-like » complex could be of the same type as the protrusions described by Geraudie (1978) at the cell surface of the pelvic fin bud of the trout.

Role of membrane protrusions in early development.

According to Boulekbache and Devillers (1977), the function of the membrane might be to increase surface exchanges, particularly respiratory exchange, between the blastomeres and their environment.

For Denis-Donini ef al. (1976) and Erickson and Trinkaus (1976), they would serve as membrane stores to be used for changes in form or for cell division. Besides these hypotheses, our observations suggest that the membrane protrusions may play a role in the specific association of the blastomeres after mitosis.

The relation between the development of deep cell membrane protrusions and changes in the mode of cellular association is evident. At first closely connected by adhesive discs at the morula stage, the blastomeres are more dispersed at mid-blastula stage when most of them have no surface specialization ; lamellipodia and filopodia (Kageyama, 1977 ; Thomas et Waterman, 1978) then appear which correspond to a mode of cell association compatible with gastrulation movements. This morphological pattern in vitro parallels that of germ " dissociativity » in a calcium-free medium (Coupe et al., 1974).

At late morula and early blastula stages, the deep cells of Fundulus heteroclitus, cultured in a physiological medium, regroup into a mass due to bleb activity (Trinkaus, 1968). The same process occurs in the trout egg, leading to the formation of the \& morula cords » (Coupe et al., 1974). In these cords, we have observed (unpublished data) that the dividing cells sever connections with neighboring cells, causing the morula cord to rupture. After mitosis, the new cells form blebs, permitting cell reassociation.

Therefore, two opposite phases in the development of membrane protrusions are seen during mitosis : in the first, the connections disappear, and in the second they are formed again.

The references cited in this study as well as our observations of Brachydanio rerio confirm that the quality and density of membrane protrusions change with the mitotic cycle. The relation is clear in the Brachydanio rerio egg, especially when the first furrows are being formed and during periblastic cell formation (smooth patches, 
microballs). On the enveloping layer when epibolic spread has smoothed out the blastomeres, it is evident that the mitoses are related to the reappearance of a complete network of cristae (fig. 5). On the contrary, deep cell division in the trout gastrula is characterized by the disappearance of filopodia and lamellipodia (Boulekbache and Devillers, 1977).

These latter two, apparently contradictory, observations agree if the membrane protrusions are postulated to have a role in the specific association of blastomeres. If, during mitosis, enveloping cell connections loosen, it is natural that membrane structures would then appear to permit the specific reassociation of daughter cells. Spiegel and Spiegel $(1977 a, b)$ have shown recently that the specific reassociation in vitro of echinoderm blastomeres includes the formation of membrane protrusions (cristae or villi). Their appearance in vitro depends on the presence in the medim of a specific substance produced by the cells and released by exocytosis (Spiegel and Spiegel, 1978). Furthermore, the SEM aspect of external folded layers in the early development of Lytechinus is very similar to that of the enveloping layer in Brachydanio rerio ; in both cases, the internal blastomere layers are smooth (Spiegel and Spiegel, 1977a).

There seems to be an anology, if not an homology, between the processes observed in the echinoderm egg and those characterizing the teleost egg. The expulsion of cortical vacuoles in both cases might release specific reassociation factors into the perivitelline medium which, with the development of the membrane cristae on the external side, would permit postmitotic reassociation of enveloping blastomeres. This would explain the difficulties (Ballard, 1973) encountered in culturing embryos after the chorion is ruptured.

As seen in the early development of the fish egg, there seems to be a correspondance between medium composition and alteration and changes in the three modes of cell association. The epithelial-type of monolayer association found in the enveloping layer would correspond to the perivitelline medium, the mass association of deep cells to the blastocoelic medium, and the syncitial type of cell association in the yolk syncitium to the yolk medium.

Reçu en novembre 1979.

Accepté en avril 1980.

Acknowledgements. - We wish to thank Mrs. S. Busson and Mr. A. Thomot for their help with the electron microscopy, Mrs. A. Daifuku who aided with the English translation, Miss R. Picard for help with the manuscript, Mr. J. Beschol-Liversac and Mrs. Guillam who permitted us to use the electron microscope facilities at the Fernand Widal Hospital, and H. Boulekbache, Ch. Devillers and C. Joly for their thoughtful advice.

Résumé. Le développement précoce des Téléostéens, en particulier pendant les stades prégastruléens est étudié en microscopie électronique à balayage (MEB) sur des œufs intacts ou fracturés de Brachydanio rerio.

Au contraire des surfaces internes lisses, la surface externe des blastomères enveloppants est garnie de crêtes qui disparaissent avec l'épibolie, ne réapparaissant alors que sur les cellules en mitose. La surface périvitelline, lisse, forme, à la fin du stade morula, un anneau de crêtes périblastiques relié, jusqu'au stade de la blastula âgée, à des « figures 
étoilées »; des images en microscopie photonique ou électronique à transmission confirment les observations de MEB sur les figures étoilées ; des hypothèses sont avancées quant à leur signification fonctionnelle.

Les cellules profondes, d'abord étroitement attachées, paraissent atteindre un degré de liberté maximum au stade de la blastula moyenne.

Au stade de la blastula intervient un bourgeonnement, à partir de syncitium périvitellin externe, de nouvelles cellules, aussi bien enveloppantes que profondes : ceci suggère, pour le syncitium périvitellin, un rôle fondamental dans la différenciation prégastruléenne.

L'hypothèse est formulée d'un rôle des projections membranaires dans l'association cellulaire spécifique venant compenser un effet dissociant de la mitose. Une relation causale est suggérée entre l'évolution de la composition des milieux biologiques présents : périvitellin, blastocoelien, vitellin, et l'évolution des modes d'association cellulaires observés : monocouche, amas, syncitium.

\section{References}

BALLARD W. W., 1973. Morphogenetic movements in Salmo gairdneri Richardson. J. exp. Zool., $184,27-48$.

BETCHAKU T., TRINKAUS J. P., 1978. Contact relations, surface activity, and cortical microfilaments of marginal cells of the enveloping layer and of the yolk syncitial and yolk cytoplasmic layers of Fundulus before and during epiboly. J. exp. Zool., 206, 381-426.

BOULEKBACHE H., 1979. Energy metabolism in fish development. Developmental biology of fish. Annu. Meet., Am. Soc. Zool. (in press).

BOULEKBACHE H., DEVILLERS C., 1977. Etude par microscopie à balayage des modifications de la membrane des blastomères au cours des premiers stades du développement de l'œuf de truite (Salmo irideus Gibb.). C. R. Acad. Sci. Paris, Sér. D, 285, 917-920.

BOULEKBACHE H., DEVILLERS C., ROSENBERG A. J., JOLY C., 1969. Corrélation entre la consommation d'oxygène ef l'activité de la L. D. $\mathrm{H}$. ef de la glucose-6-phosphate déshydrogénase au cours des premiers stades du développement de l'œuf de truite, Salmo irideus. C. R. Acad. Sci. Paris, Sér. D, 268, 2211-2214.

BOULEKBACHE H., DEVILLERS C., ROSENBERG A. J., JOLY C., 1971. Action de l'acide oxamique, inhibiteur spécifique de la lactico-déshydrogénase sur les premiers stades du développement de l'œuf de truite (Salmo irideus Gibb.). C. R. Acad. Sci. Paris, Sér. D, 272, 114-116.

BOULEKBACHE H., ROSENBERG A. J., JOLY C., 1970. Isoenzyme de la lactycodéshydrogénase au cours des premiers stades de développement de l'œuf de truite (Salmo irideus Gibb.). C. R. Acad. Sci. Paris, Sér. D, 271, 2414-2417.

BOULEKBACHE H., ROUBAUD P., DEVILLERS C., 1976. Localisation histochimique de la lacticodéshydrogénase dans l'embryon de la truite (Salmo irideus Gibb.), au cours de l'organogenèse précoce de la corde et du tube neural. C. R. Acad. Sci. Poris, Sér. D, 284, 381-384.

BUSSON-MABILLOT S., 1971. Influence de la fixation chimique sur les ultrastructures. J. Microsc., 12, 317-348.

COUPE R., BOULEKBACHE H., ROUBAUD P., DEVILLERS C., 1973. Etude de la dissociation cellulaire in vitro sur les premiers stades du développement embryonnaire de la truite (Salmo irideus Gibb.). C. R. Acod. Sci. Paris, Sér. D, 277, 353-356.

COUPE R., BOULEKBACHE H., ROUBAUD P., DEVILLERS C., 1974. Evolution de la dissociativité des blastomères de l'embryon de truite (Salmo irideus Gibb.) au cours des premiers stades du développement. C. R. Acad. Sci. Paris, Sér. D, 279, 1549-1552.

DENIS-DONINI S., BACCETTI B., MONROY A., 1976. Morphological changes of the surface of the eggs of Xenopus laevis in the course of development. J. ultrastruct. Res., 57, 104-112.

ERICKSON C. A., TRINKAUS J. P., 1976. Microvilli and bleds as sources of reserve surface membrane during cell spreading. Exp. Cell Res., 99, 375-384.

GERAUDIE J., 1978. Scanning electron microscopy study of the developing trout pelvic fin bud. Anat. Rec., 191, 391-396.

GIPSON I., 1974. Electron microscopy of early cleavage furrows in the chick blastodisc. J. ultrastruct. Res., 49, 331-347. 
HART N. H., YU S. F., GREENHUT V. A., 1977. Observations on the cortical reaction in eggs of Brachydanio rerio as seen with the scanning electron microscope. J. exp. Zool., 201, 325-331.

KAGEYAMA T., 1977. Motility and locomotion of embryonic cells of the medaka Oryzias latipes, during early development. Develop. Growth Differ., 19, 2, 103-110.

KOPSCH F., 1898. Die Entwicklung der äusseren Form des Forellen embryo. Archiv. mikr. Anot., 51, 189-213.

ROUBAUD P., BOULEKBACHE H., DEVILLERS C., JOLY C., 1976. Localisation histochimique de la lactico-déshydrogénase dans les blastomères au cours du développement précoce de l'embryon de la truite arc-en-ciel (Salmo irideus Gibb.). C. R. Acod. Sci. Paris, Sér. D, 283, $1543-$ 1546.

SPIEGEL E., SPIEGEL M., 1977a. A scanning electron microscope study of early sea urchin reaggregation. Exp. Cell Res., 108, 413-420.

SPIEGEL E., SPIEGEL M., 1977b. Microvilli in sea urchin eggs. Exp. Cell Res., 109, 462-465.

SPIEGEL E., SPIEGEL M., 1978. Specific cell adhesion in echinoderm embryonic cells. Conf., Lab. Embryol., Collège de France, Nogent-sur-Marne.

THOMAS R. J., WATERMAN R. E., 1978. Gastrulation in the teleost Brachydanio rerio. In Scanning Electron Microscopy, Vol. Il (S. E. M. Inc.), 531-540, A. M. F. O'HARE, II, 6066, U. S. A.

TRINKAUS J. P., 1968. In Cells into organs, Found, of Dev. Biol., Prentice Hall Ed., p. 187. 